一般病棟に打ける除菌剤を用いた環境表面清拭回数と付着細菌数の 減少効果に関する検討

\author{
伊藤 重彦 1,7$) \cdot$ 中川 祐子(1,7) 南 博子2) 橋本 治 ${ }^{3)} \cdot$ 堀江 恭子 4 ) \\ 樋渡 美紀5) $\cdot$ 諸永 幸子6) $\cdot$ 元石 和世7) ·谷口 初美7) $\cdot$ 松本 哲朗7)
}

\title{
Relationship of Frequency of Wiping with Disinfectant and Decrease in Bacteria on Environmental Surfaces in General Wards
}

Shigehiko Ito ${ }^{1,7)}$, Yuko NakAgawa ${ }^{1,7)}$, Hiroko Minami $^{2)}$, Osamu Hashimoto ${ }^{3)}$, Yasuko HoriE ${ }^{4)}$, Miki Hiwatashi $^{5)}$, Yukiko Moronaga ${ }^{6)}$, Kazuyo Motoishi ${ }^{7)}$, Hatsumi TAniguchi ${ }^{7)}$ and Tetsuro Matsumoto ${ }^{7)}$

1) Division of Infection Control and Prevention, Kitakyushu City Yahata Hospital,

${ }^{2)}$ Department of Infection Control and Prevention, Tobata Kyoritsu Hospital,

3) Department of Pharmacy, Tobata Kenwa Hospital,

4)Division of Infection Control and Prevention, Japan Community Health care Organization Kyushu Hospital,

5) Division of Infection Control and Prevention, Shinyukuhashi Hospital,

6) Division of Infection Control and Prevention,Kenwakai Otemachi Hospital,

7) NPO corporation KRICT

(2015 年 11 月 11 日 受付 $\cdot 2016$ 年 3 月 15 日 受理)

要 旨

一般病棟に抢ける除菌剂含有ワイプによる清拭回数と環境表面付着細菌数の減少効果について検 討した.

1 施設の外科病棟において, 複数箇所の環境表面を対象に付着細菌数を測定した. その結果, 一 般細菌生菌数 (生菌数) が多かった病棟患者用トイレの便座, 洗浄操作パネル, 手洗い場蛇口周囲の 3 箇所の環境表面を対象に, 6 施設が参加して, 清拭回数と除菌効果について検討した. 各施設が 準備した 2 つのイレを $\mathrm{A}$ 群(1日 1 回清拭群), B 群(1日 2 回清拭群)の 2 群にわけ, 除菌剤含有 ワイプを用いて清拭した。連続した 5 日間において. 調査 1 日目， 2 日目， 5 日日朝の清拭前に環 境表面から検体を採取し, 全菌数, 生菌数, アデノシン三リン酸 (ATP 值)を測定した. 清拭方法 は 6 施設で統一し，ペルオキソー硫酸水素カリウム(酸化剤)配合剤含有ワイプを用いた.

洗浄操作パネル, 手洗い場蛇口周囲に掠いて, B 群の生菌数は調査 1 日目, 2 日目, 5 日日にか けて減少した $(\mathrm{p}<0.05)$. ATP 值は, 洗浄操作パネル, 手洗い場蛇口周囲で A 群, B 群ともに低 下した $(\mathrm{p}<0.05)$. 手洗い場蛇口周囲の全菌数, 生菌数は, 清拭直後に有意な減少を認めなかった. 除菌剤含有ワイプによる清拭回数を 1 日 1 回から 1 日 2 回に増やすと, 一般病棟患者用トイレ の複数箇所において環境表面全菌数, 生菌数が経日的に減少した.

Key words : 環境整備, 病院感染, 環境消毒, 除菌剤, 清拭

1) 北九州市立八幡病院感染制御室， 2 ) 戸畑共立病院感染制御室， 3) 戸畑けんわ病院薬剂科, ${ }^{4)} \mathrm{JCHO}$ 九州病院感染制御室, 5)新行 橋病院感染制御室, 6) 健和会大手町病院感染制御室, 7) NPO 法 人 KRICT
はじめに

病院感染対策の基本は標準予防策であるが，近年，環 境整備の重要性を指摘する報告が増えている ${ }^{1,2)}$ 。その ため, 多くの医療機関が環境整備に積極的に取り組んで 


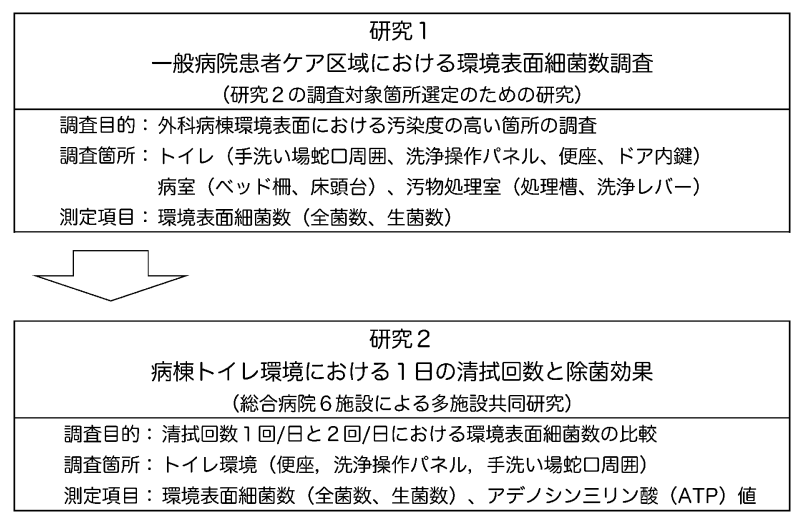

図 1 研究 1 , 研究 2 の概要

いるが，整備方法や実施回数が感染予防に及ぼす影響, 効果についていまだ十分な研究が行われていない. CDC (米国疾病予防管理センター; Centers for Disease Control and Prevention)は環境表面をノンクリティカル に区分し, 病院内の高頻度接触部位に対して 1 日 1 回 以上の消毒薬や除菌剂を用いた清拭を推奨している ${ }^{3)}$. そこで, 除菌剤を用いた 1 日あたりの清拭回数が環境 表面細菌数に及ぼす影響を調査する目的で，図１に示す ような手順で研究 1 と研究 2 を行った. 研究 1 は, 一 般病院患者ケア区域における環境表面細菌数の調査であ る. 研究 2 は, 複数施設の病棟トイレ環境表面におい て, 除菌剂含浸ワイプによる 1 日 1 回の清拭と 1 日 2 回の清拭の除菌効果に関する調査である.

なお, 研究 1 および研究 2 は, 杏林製薬株式会社. キョーリンメディカルサプライ株式会社の委託研究であ り, 研究 2 は北九州地域の急性期病床を有する 6 医療 機関が参加した多施設共同研究である.

\section{対象および方法}

1. 研究 1: 一般病棟における環境表面細菌数の調査

清拭回数が環境表面細菌数に及ぼす影響に関する調査 を行うにあたり, 一般病棟患者ケア区域のなかで, 複数 箇所の環境表面細菌数〔全菌数, 一般細菌生菌数(以下 生菌数)】を調査し, 污染度の高い箇所を特定した。

\section{1) 対象}

北九州市立八幡病院 (以下 当院)外科病棟において環 境表面一般細菌数を 2013 年 10 月 29 日と 11 月 20 日の 2 回に分けて調査した. 2013 年 10 月 29 日の調査対象 は, 患者用トイレAのトイレ手洗い場蛇口周囲, 洗浄 用操作パネル，ドアノブ内鍵部分，殿部が接触する側の 便座表側 (以下 便座), 污物処理室の污物処理槽 $\mathrm{A}$, 病室 $\mathrm{A}$ のベッド柵と床頭台, 病棟会議室 $\mathrm{A}$ のテーブル からそれぞれ 1 箇所ずつ計 8 箇所の環境表面とした。 11 月 20 日の調査対象は， 10 月 29 日と異なるトイレ B の洗浄用操作パネル, ドアノブ内鍵部分, 便座抢よび便
座裏側, 污物処理室の污物処理槽 B, 洗浄レバーのそれ ぞれ 1 箇所ずつ計 6 箇所の環境表面とした.

\section{2）方法}

検体採取は滅菌手袋を着用したのち清潔操作下で行っ た. 調査対象箇所の環境表面 $10 \mathrm{~cm} \times 10 \mathrm{~cm}$ 範囲からス ワブ拭き取り法で検体を採取し，拭き取り部分のみを消 毒したはさみで切断後, $0.5 \mathrm{~mL}$ 滅菌リン酸緩衝液に投 入し，ボルテックスミキサーで 30 秒間懸濁したものを 試料水とした. この試料水を用いて全菌数, 生菌数, 生 菌率 (全菌数に占める生菌数の割合 ; \%) を測定, 算出し た。

\section{2. 研究 2 : 病棟トイレ環境における 1 日の清拭回数 之除菌効果 (多施設研究)}

急性期病床を有する 6 つの病院が参加し, 病棟患者 用トイレにおける環境表面清拭回数と除菌効果について 検討した.

\section{1）対象}

調査に参加した施設は，NPO 法人 KRICT に所属す る, 当院, 戸畑共立病院, 戸畑け九わ病院, JCHO 九州 病院, 新行橋病院, 健和会大手町病院の 6 施設であ る. それぞれ清拭回数の異なる 2 箇所の病棟患者用卜 イレを準備し，A 群(1日 1 回清拭群)，B 群(1日 2 回 清拭群)の 2 群に分けた. トイレ内の調査箇所は, 便 座, 洗浄操作パネル, 手洗い場蛇口周囲の 3 箇所の環 境表面とした。

\section{2）方法}

調査は 3 施設ずつ 2 期に分け， 2014 年 1 月 21 日〜 24 日の連続する 5 日間と 1 月 27 日〜 31 日の連続する 5 日間で行った．各施設が用意した 2 箇所のトイレを $\mathrm{A}$ 群，B群にわけ，環境整備方法を十分理解した看護師が 便座，洗浄操作パネル，手洗い場蛇口周囲の 3 箇所の 環境表面を除菌剂含有のワイプにより清拭した。A 群 は毎日午前中 $(9$ 時〜 11 時)に 1 回， B 群は毎日午前中 (9 時〜 11 時) と日勤帯終了前(15 時〜 16 時)の 2 回, 清 拭を行った。除菌剤は全施設で統一し，ペルオキソー硫 酸水素カリウム(酸化剂)配合除菌・洗浄剂(ルビスタ ${ }^{\circledR}$, 杏林製薬㧣；以下 RST)を用いた。1 回の清拭には， RST 1 包 (5 g) を水道水 $500 \mathrm{~mL}(500 \mathrm{~g})$ に溶解した $1 \%$ $(\mathrm{w} / \mathrm{v})$ 調製液を含有したワイプ 1 枚を用いた。清拭方法 を統一するため, 調査箇所の清拭は， 6 施設の研究協力 者(本論文の共著者)，または清拭手順を事前に説明され た看護師が行った。具体的な手順は，ワイプ 1 枚を半 分に折りたたみ，便座と水道蛇口周囲に沶いては向かっ て左側 (ATP 測定箇所)を拭き残しがないよう注意しな がら，環境表面に十分接触するように押しつけ，奥から 手前に 1 回清拭した. 次にワイプを新しい面にひっく り返し，同様に右側 $\{$ 細菌培養箇所 $\}$ の調査箇所を 1 回清拭した(図 2). 洗浄操作パネルは, 図 2 に示すよう 


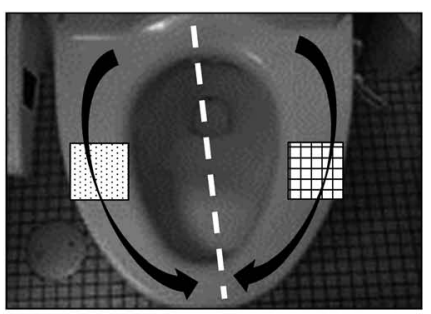

(1) トイし便座

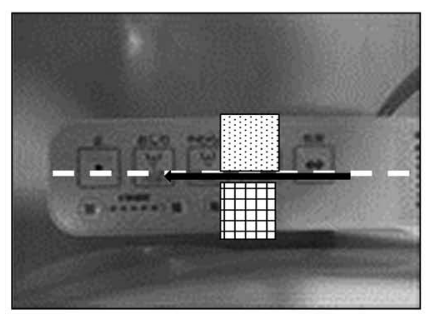

(2) 洗浄操作パネル

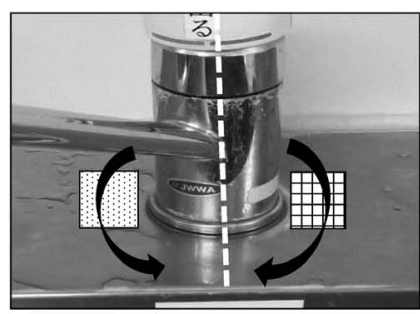

(3) 手洗い場蛇口周囲

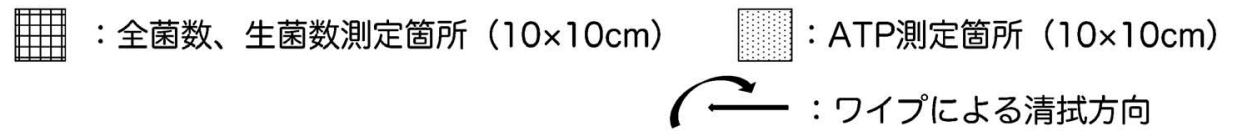

図 2 病棟患者用トイレの環境表面調査箇所とその方法

に，半分に折りたたんだワイプで表面全体を奥から手前 に 1 回清拭した.

各施設の $\mathrm{A}$ 群， $\mathrm{B}$ 群の検体採取は，同じ期間，同じ 日時に行った。両群とも調査開始 1 日目, 2 日目, 5 日 目の午前 1 回目の清拭前に, 予め調査箇所に定めた環 境表面 $10 \mathrm{~cm} \times 10 \mathrm{~cm}$ 範囲から検体を 1 回採取した（図 2). また, RST 含有ワイプによる清拭直後の除菌効果 を評価するため, 調査 2 日目午前の清拭前と清拭 5 分 後に, 同じ環境表面から検体を 1 回採取した。採取し た検体を用いて, 環境表面の全菌数, 生菌数, アデノシ ン三リン酸 (adenosine triphosphate ; 以下ATP)值を測 定した.

\section{3. 細菌学的評価方法}

環境表面一般細菌の全菌数, 生菌数測定は, 産業医科 大学微生物学教室で行った. ATP 測定は, ATP 測定機 種, 測定方法を統一し, 各施設に掞いて測定した.

\section{1) 全菌数 (cells $/ \mathrm{mL}$ ) 測定手順}

全菌数 $(\mathrm{cells} / \mathrm{mL})$ 測定は, エチジウムブロマイドによ る蛍光染色法を用いた ${ }^{4)}$. 試料水をフィルター $(0.2 \mu \mathrm{m}$ 孔径)をセットしたろ過器で吸引ろ過した後, エチジウ ムブロマイド水溶液 $(100 \mu \mathrm{g} / \mathrm{L})$ を加え染色した. フィ ルターを無蛍光オイルでカバーグラス間に封入し, 落射 型蛍光顕微鏡で検鏡, 1 サンプルにつき 30 視野で細菌 様の形状の物を計数し試料水 $1 \mathrm{~mL}$ 中の菌数を 2 回測定 し, 平均全菌数を求めた.

\section{2) 生菌数 $(\mathrm{cfu} / \mathrm{mL})$ 測定手順}

生菌数 $(\mathrm{cfu} / \mathrm{mL})$ 測定には好気培養法を用いた ${ }^{5)}$. 研 究 1 で述べた方法で作成した試料の 10 倍希釈系列を作 製し, 異なる 2 点または 3 点の希釈倍率の菌液 $0.1 \mathrm{~mL}$ を一般細菌検査用の SCD 寒天培地 2 枚に接種した. 30 ${ }^{\circ} \mathrm{C}$ にて培養を行い, 1 週間後に菌数を測定し平均生菌数 を求めた．本検査法の培養条件でコロニーを形成する一 般細菌のみを測定した。

\section{3) ATP 値 (RLU) 測定手順}

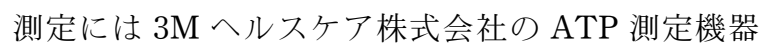

$\left(3 \mathrm{M}^{\mathrm{TM}}\right.$ クリーントレース ${ }^{\mathrm{TM}} \mathrm{ATP}$ 測定用ルミノメー ター UNG3，3 $3 \mathrm{M}^{\mathrm{TM}}$ クリーントレース ${ }^{\mathrm{TM}} \mathrm{ATP}$ 測定用試 薬 UXL100)を用いた。清潔操作下に専用スワブにより 予め定めた $10 \mathrm{~cm} \times 10 \mathrm{~cm}$ の範囲の環境表面を拭き取り, ATP 測定用試薬と速やかに反応させたのち ATP 值 (Relative Light Unit; RLU) を測定した6).

\section{4. 分析方法}

全菌数, 生菌数, ATP 值はすべて常用対数 $\left(\log _{10}\right)$ で 表示した. 調査 1 日目を基準值とし， 2 日目，5 日目に かけての菌数および ATP 值の変化を統計学的に検討し た. 統計学的有意差検定には, 反復経時測定分散分析, post hoc 検定を用い，有意水準 5\%未満を有意差ありと 判定した。清拭回数の異なる 2 群で, 連続 5 日間の 時間経過に打ける菌数減少傾向を比較するため, Bonferroni 法を用いて検討した. 統計ソフトは, Easy R (EZR; GNU General Public License version 2, version 3）を使用した.

\section{結果 \\ 1. 一般病棟における環境表面細菌数の調査}

当院外科病棟内の調查箇所別の全菌数および生菌数の 結果を示す(表 1). 生菌数が多かったのは, 病棟患者用 トイレの便座, 洗浄操作パネル, 手洗い蛇口周囲の環境 表面で, 全菌数に占める生菌数の割合 $\left(\log _{10}\right.$ 生菌数/ $\log _{10}$ 全菌数) は, トイレ手洗い場蛇口周囲, 洗浄操作パ ネル，便座の順で高かった．環境表面付着細菌数におい ては, 死菌を含む全菌数ではなく, 生体に定着・感染 し, 発病させうる生菌数が直接病院感染に影響すると考 えられることから, 研究 2 の調査対象は, 生菌数が多 かった病棟患者用トイレの便座, 洗浄操作パネル, 手洗 い場蛇口周囲 3 箇所の環境表面に決定した.
2. 病棟患者用トイレの環境表面に対する清拭回数と 除菌効果
1） 清拭回数別の全菌数の推移 (図 3)
6 施設における連続 5 日間の調査において, A 群の環 
表 1 外科病棟における調査箇所別の全菌数, 生菌数

\begin{tabular}{|c|c|c|c|c|}
\hline 環境表面調査箇所 & 調査時期 & $\begin{array}{c}\log _{10} \text { 全菌数 } \\
(\mathrm{cells} / \mathrm{mL})\end{array}$ & $\begin{array}{c}\log _{10} \text { 生菌数 } \\
(\mathrm{cfu} / \mathrm{mL})\end{array}$ & $\begin{array}{c}\text { 生菌率 (\%) } \\
\text { (生囷数/全菌数) }\end{array}$ \\
\hline \multicolumn{5}{|l|}{ 病棟患者用トイレ } \\
\hline トイレ A 手洗い蛇口周囲 & $2013 / 10 / 29$ & 5.4 & 4.6 & 85.2 \\
\hline トイレ A 洗浄操作パネル & $2013 / 10 / 29$ & 4.0 & 1.2 & 30 \\
\hline トイレ B 洗浄操作パネル & $2013 / 11 / 20$ & 5.9 & 3.9 & 66.1 \\
\hline トイレAドア内鍵部分 & $2013 / 10 / 29$ & 3.8 & 1.0 & 26.3 \\
\hline トイレ B ドア内鍵部分 & $2013 / 11 / 20$ & 3.5 & 0.0 & 0 \\
\hline トイレ A 便座表側 & $2013 / 10 / 29$ & 4.8 & 2.1 & 43.8 \\
\hline トイレ B 便座表側 & $2013 / 11 / 20$ & 3.9 & 1.5 & 38.4 \\
\hline トイレ B 便座裏側 & $2013 / 11 / 20$ & 4.5 & 1.0 & 22.2 \\
\hline \multicolumn{5}{|l|}{ 污物処理室 } \\
\hline 污物処理槽 A & $2013 / 10 / 29$ & 4.3 & 0.7 & 16.3 \\
\hline 污物処理槽 B & $2013 / 11 / 20$ & 4.5 & 0.7 & 15.6 \\
\hline 污物処理槽 B 洗浄用レバー & $2013 / 11 / 20$ & 3.2 & 0.0 & 0 \\
\hline \multicolumn{5}{|l|}{ 外科病棟病室 (4 人部屋) } \\
\hline 病室 A ベッド柵 & $2013 / 10 / 29$ & 3.6 & 1.0 & 27.8 \\
\hline 病室 A 床頭台 & $2013 / 10 / 29$ & 4.0 & 1.0 & 25 \\
\hline 病棟会議室 A テーブル & $2013 / 10 / 29$ & 5.4 & 1.0 & 18.5 \\
\hline
\end{tabular}

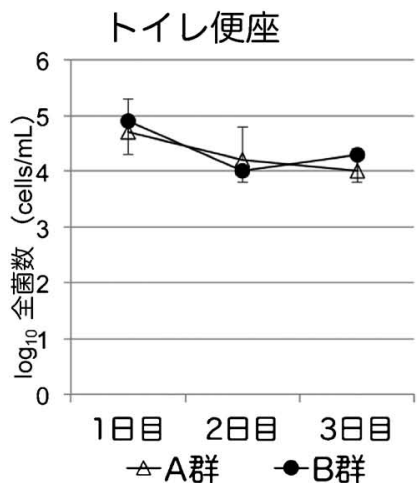

\begin{tabular}{|c|c|c|c|c|}
\hline \multicolumn{2}{|c|}{$\log _{10}$ 全菌数 } & 1日目 & 2日目 & 5日目 \\
\hline \multirow{2}{*}{ A群 } & mean & 4.7 & 4.2 & 4 \\
\cline { 2 - 5 } & SD & 0.6 & 0.6 & 0.4 \\
\hline \multirow{2}{*}{ B群 } & mean & 4.9 & 4 & 4.3 \\
\cline { 2 - 5 } & $S D$ & 0.6 & 0.2 & 0.5 \\
\hline
\end{tabular}

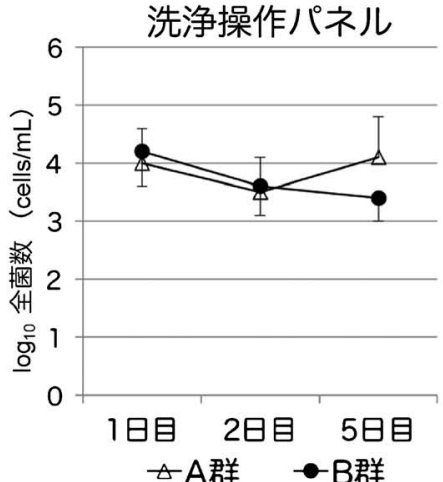

$$
\triangle \mathrm{A} \text { 群 } \rightarrow \mathrm{B} \text { 群 }
$$

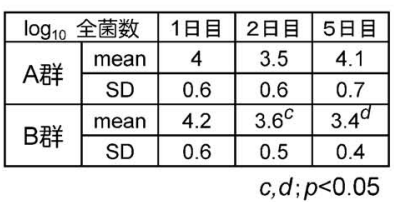

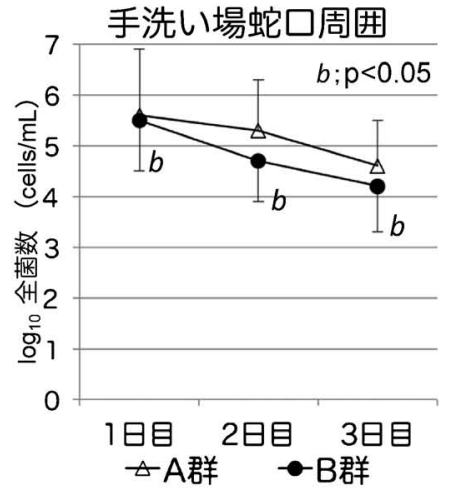

\begin{tabular}{|c|c|c|c|c|}
\hline \multicolumn{2}{|c|}{$\log _{10}$ 全菌数 } & 1日目 & 2日目 & 5日目 \\
\hline \multirow{2}{*}{ A群 } & mean & 5.6 & 5.3 & 4.6 \\
\cline { 2 - 5 } & SD & 1.3 & 1 & 0.9 \\
\hline \multirow{2}{*}{ B群 } & mean & 5.5 & 4.7 & 4.2 \\
\cline { 2 - 5 } & $S D$ & 1 & 0.8 & 0.9 \\
\hline
\end{tabular}

$b$; 反復経時測定分散分析 $c$ (2日目vs1日目)、d(5日目vs1日目); post hoc検定

\section{図 3 清拭回数別の環境表面全菌数の推移}

境表面全菌数は, 便座, 洗浄操作パネル, 手洗い場蛇口 周囲のいずれの箇所でも，調査開始 1 日目， 2 日目， 5 日目にかけて有意な変動はなかった。一方 B 群では, 手洗い場蛇口周囲の全菌数は 1 日目, 2 日目, 5 日目に かけて有意に減少した $(\mathrm{p}<0.05)$. また, 便座, 洗浄操 作パネルの全菌数も 1 日目, 2 日目, 5 日目にかけて減 少傾向を認めたが有意差は認めなかった。また，1日目
の基準值と 2 日目抢よび 5 日目で全菌数を比較したと ころ, $\mathrm{B}$ 群洗浄操作パネルの 2 日目および 5 日目の全 菌数は基準值に比べ有意に少なかった $(\mathrm{p}<0.05)$.

\section{2） 清拭回数別の生菌数の推移（図 4)}

6 施設における連続 5 日間の調査において，便座の生 菌数は $\mathrm{A}$ 群と B 群で差がなかった. 一方, 洗浄操作パ ネルの生菌数は, A 群, B 群共に 1 日目, 2 日目, 5 日 

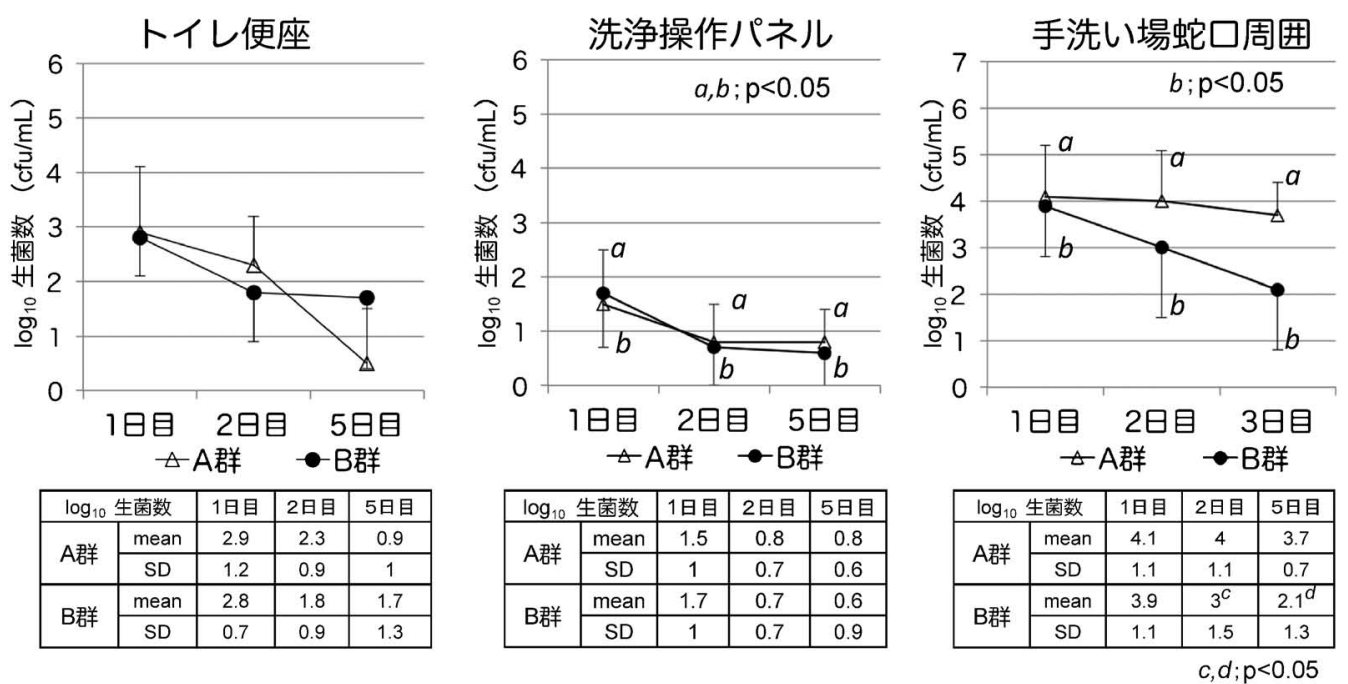

$a, b$; 反復経時測定分散分析 $c$ (2日目vs1日目)、d(5日目vs1日目); post hoc検定

図 4 清拭回数別の環境表面生菌数の推移
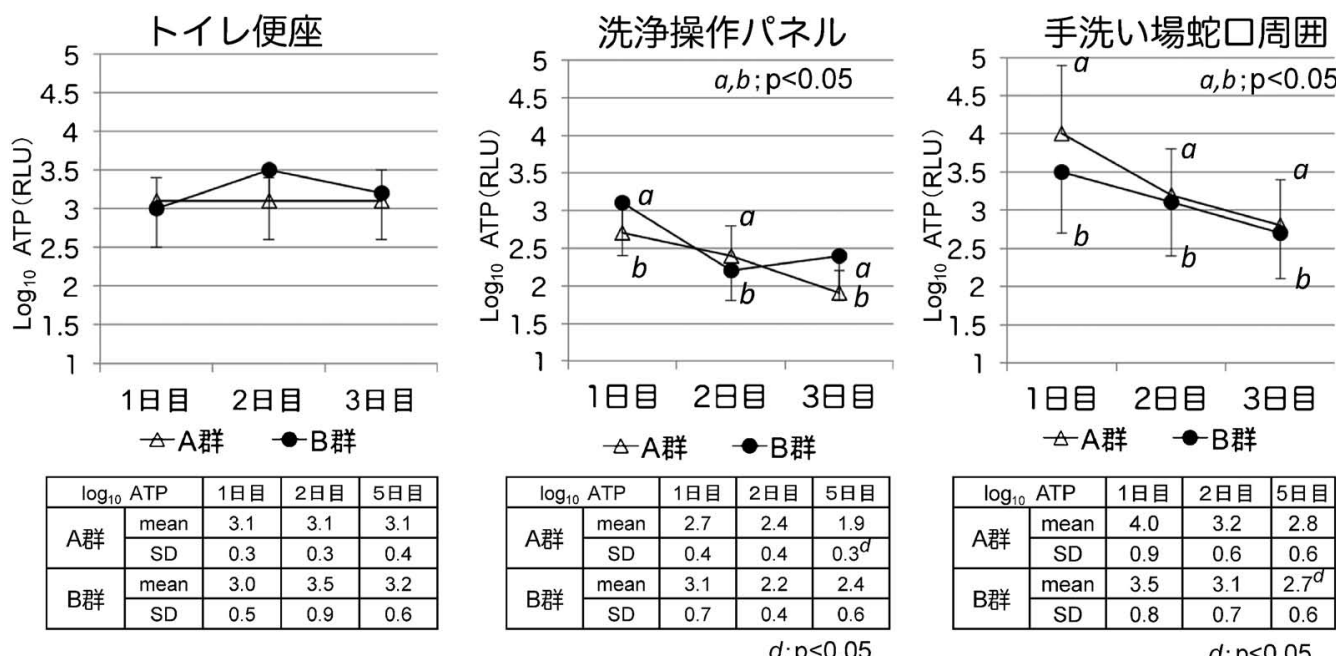

$a, b$; 反復経時測定分散分析 $c(2$ 日目vs1日目)、d(5日目 vs1日目); post hoc検定

図 5 清拭回数別の環境表面 ATP 值の推移

目にかけて減少した $(\mathrm{p}<0.05)$. 手洗い場蛇口周囲の生 菌数は, A 群では有意な変化がなかったが, B 群では 1 日目，2 日目，5 日目にかけて有意に減少した $(\mathrm{p}<$ $0.05)$ 。また， 1 日目の基準值と 2 日目および 5 日目の 生菌数を比較したところ, B 群洗浄操作パネルの 5 日目, $\mathrm{B}$ 群手洗い場蛇口周囲の 2 日目および 5 日目の生菌数 は基準值より有意に少なかった $(\mathrm{p}<0.05)$.

\section{3） 清拭回数別の ATP 値の推移（図 5)}

6 施設に抢ける連続 5 日間の調査に打いて, 便座の ATP 值は, A 群, B 群共に有意な変化はなかった。一 方, 洗浄操作パネルの ATP 值は A 群, B 群の両群にお いて，手洗い場蛇口周囲の ATP 值はB 群において，有 意に低下した $(\mathrm{p}<0.05)$.
4）清拭直後の全菌数, 生菌数, ATP 值の推移 (図 6)

RST 含有ワイプ清拭 5 分後の環境表面全菌数と生菌 数は, 清拭前に比べ便座, 洗浄操作パネルで有意に減少 した $(\mathrm{p}<0.05)$. 一方, RST 含有ワイプ清拭 5 分後の手 洗い場蛇口周囲の全菌数, 生菌数は, 清拭前に比べ減少 しなかった。清拭 5 分後のATP 值は, 便座, 手洗い場 蛇口周囲に抢いて有意に減少し $(\mathrm{p}<0.05)$, 洗浄操作パ ネルに颃ても減少傾向を示したが，有意差は認めなか った。

\section{考察}

環境表面の微生物污染による院内感染では, 環境表面 に長期間生存するウイルスや細菌に接触した病院職員の 

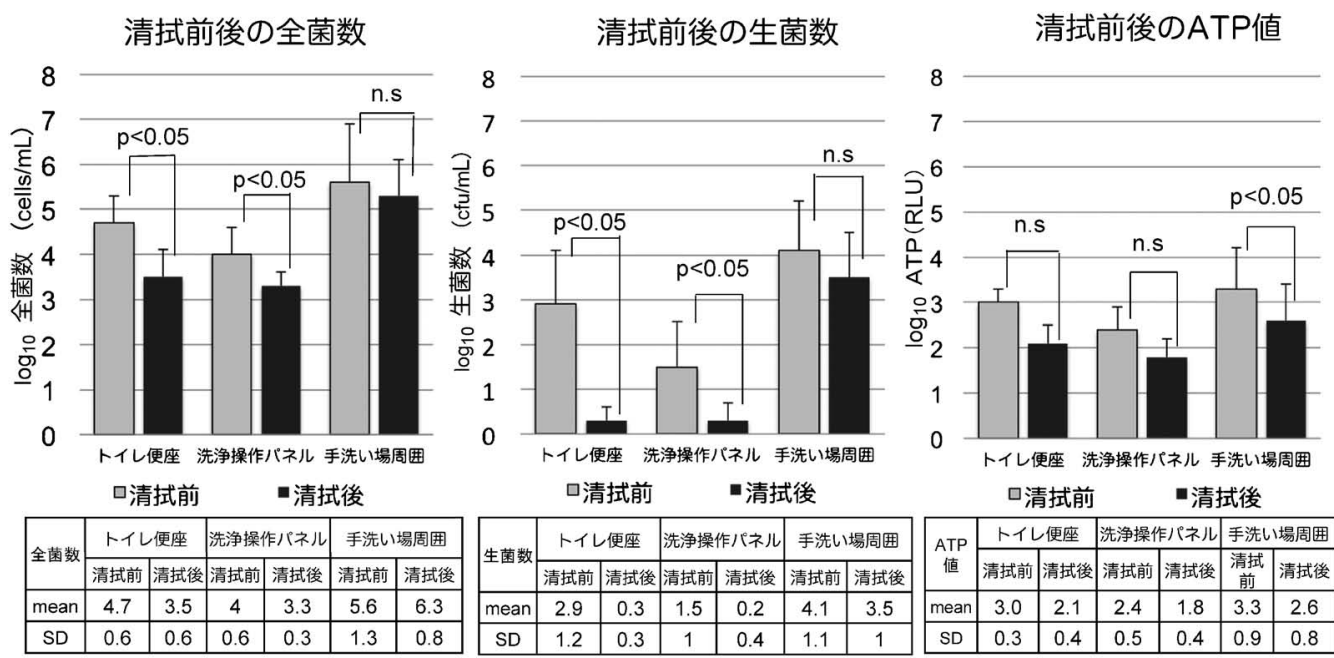

図 6 清拭直後 (5 分後)の環境表面全菌数, 生菌数, ATP 值の推移

手を介した伝搬が原因となることが多い7,8).そこで， 患者ケア区域に掞いては, 環境表面付着菌量の減少のた めの定期的な環境整備が推奨されている ${ }^{9,10)}$. 一般的に は, 患者または職員が高頻度に接触する環境表面の污染 度は高いと考えられている. しかし, 今回の当院外科病 棟に打ける調査では, 高頻度接触部位といわれる入院患 者用ベッド柵や床頭台の環境表面の生菌数は $10 \mathrm{cfu} / \mathrm{mL}$ 以下であった. 他の調査箇所に比べて予想以上に生菌数 が少なかったのは, 接触頻度の高い部位は環境表面整備 が必要であることを普段から意識し, 丁寧な清拭が行わ れている結果と思われる11)。病院職員にとって污物処 理室は污染度の高い場所という認識があり, 污物処理室 内の作業では個人防護具を着用することが多い.今回の 調査で, 污物処理室は全菌数が多い割に生菌数が少ない 場所であった. 生菌数が最も多かったのは病棟トイレ環 境表面で, 手洗い蛇口周囲, 洗浄操作パネル, 便座の順 に生菌数が多かった. ノロウイルスなど感染性腸炎の原 因ウイルス，バンコマイシン耐性腸球菌 (vancomycinresistant Enterococcus: VRE), 多剂耐性緑膿菌 (multidrug resistant Pseudomonas aeruginosa: MDRP), Clostridium difficile 腸炎などは, トイレ環境表面の污染を介 して患者や職員に伝搬しやすいことから, 可能な限り頻 回の消毒が必要である.

耐性菌アウトブレイクなど病院内での感染症が流行し ている場合を除き，一般病棟に打ける日常的な環境整備 回数は 1 日 1 回, 多くて 2 回が一般的と思われる. 研 究参加 6 施設の環境整備回数は, すべて 1 日 1 回であ った。また，結果には明記しなかったが，2015 年 11 月 26 日から 12 月 2 日の期間で NPO 法人 KRICT に参加 している医療機関 35 施設に対して環境整備回数のアン ケート調査を行ったところ，1 日 1 回が 31 施設 (88\%), 2 回が 2 施設 $(6 \%)$ で, 多くの施設で環境整備回数が 1
日 1 回であった.しかしながら，1日 1 回の環境整備で 十分であるかどうかを具体的に検討した報告はない。 CDCは, ドアノブ, ベッド柵, スイッチ, 病室トイレ のなかや周囲表面など頻回に触れる場所は, あまり触れ ない場所より頻繁の清掃, 1 日 1 回以上の消毒を推奨し ているが，日常的に消毒すべき場所，適切な消毒回数に ついて具体的な指針を示していない3,12).

環境表面を清拭した後に新たな細菌污染があった場 合，あるいは残存する生菌が次回の清拭までの間で菌数 が増加し, 環境表面を介して細菌が病棟患者や職員に定 着する機会が増す。一方, 清拭回数を 1 日 1 回から 2 回に増やすと, 清拭から清拭までの間隔が短くなる結 果, 次回清拭までに増える細菌数をある程度抑えること で, 環境表面を介した患者細菌伝播のリスクは低くなる と考えられる。そこで研究 2 に打いて, A 群(1日 1 回 清拭群) と B 群(1日 2 回清拭群)で清拭と清拭の間隔の 違いによる環境表面細菌数の変化を比較した。連続 5 日間の RST 含有ワイプによる清拭効果については，そ れぞれの群で調査開始 1 日目の環境表面細菌数を基準 值とし， 2 日目と 5 日目の細菌数の変化を評価した． 6 施設の患者用トイレ 3 箇所の環境表面生菌数の変化を 2 群間で比較したところ. A 群に比べ B 群において. 調 查開始 1 日日より生菌数が経時的に減少する箇所が増 えた.この結果から，一般病棟の患者用トイレ環境にお いては, 清拭回数 1 日 1 回より 1 日 2 回のほうが，環 境表面生菌数を少ない状況で維持できる可能性が示唆さ れた. 1 日 2 回の清拭回数は多忙な病棟業務のなかでも 十分実施可能である. 清拭と清拭の間隔を短くすること で環境表面生菌数を低く抑えることができる箇所が増え ることは，病院感染予防にも慗がると思われる．

RST 含有ワイプを用いて清拭した直後 (5 分後)の全 菌数, 生菌数は, 便座, 洗浄操作パネルで有意に減少し 
たが，手洗い場蛇口周囲では減少しなかった．除菌効果 が不十分となった理由としては, 蛇口周囲に残っている 水滴で清拭圧が不均一となり付着菌を物理的に十分除去 できなかったこと，あるいはワイプが過剩な水分を吸収 することで除菌剂濃度が低下し, 十分除菌できなかった ことなどが考えられる. 水回りなど水滴が多い環境表面 に対しては, ガーゼまたはペーパーで環境表面の水分を 一度十分に拭き取った後に, 改めて規定量の消毒薬, あ るいは除菌剤を含有したワイプで丁寧に清拭すべきであ る. Rutala らは, 芽胞を形成したClostridium difficile による環境表面污染に対しては, 薬剤による化学的殺菌 より適切に実施したワイプ清拭による物理的除去で菌減 少効果が高かったと報告している13). 不適切な清拭操 作は環境表面の污染を広げる可能性があることから, 規 定量の薬剤を含浸したワイプは環境表面に確実に密着さ せ, 丁寧に清拭することが重要である.

\section{結 語}

（1）患者ケア区域において, 環境表面細菌数(とくに生 菌数)が多い箇所の一つがトイレであった。感染対策 上，環境整備が必要な場所である.

(2) 除菌剤含有ワイプによる清拭回数を 1 日 1 回から 1 日 2 回に増やすと, 一般病棟患者用トイレの複数箇所 において環境表面全菌数, 生菌数が経日的に減少した.

（3）水分の多い環境表面に抢いては，まず表面の水分 を十分拭き取ったのちに除菌剤含有ワイプで清拭すべき である.

謝 辞 : 研究にご協力頂いた山崎裕太氏 (戸畑共立病院), 三井 あゆみ氏 (市立八幡病院), 秋吉裕子氏 $(\mathrm{SMART} \cdot \mathrm{LLP})$ 山口征 啓氏 (健和会大手町病院), 芳賀由美氏 (JCHO 九州病院) の皆さ んに感謝します.

本研究の一部は, 第 30 回日本環境感染学会において発表し た.

利益相反自己申告：申告すべきことなし．

\section{文献}

1) Rutala WA, Weber DJ: The benefits of surface disinfection. Am J Infect Control 2004; 27: 226-31.
2) Weber DJ, Anderson D, Rutala WA: The Role of the Surface Environment in Healthcare-Associated Infection. Curr Open Infect Dis 2013; 26: 338-44.

3) Sehulster L, Chinn RY; CDC; HICPAC: Guideline for environmental infection control in health-care facilities. Recommendations of $\mathrm{CDC}$ and the Healthcare Infection Control Practices Advisory Committee (HICPAC). MMWR Recomm Rep 2003; 52(RR-10): $1-42$.

4）邑瀬章文, 内山知二, 山口進康, 那須正夫 : 蛍光染色 法による地下水中の細菌数評価. 防菌防徽 1999; 27: 785-92.

5）第十五改正日本薬局方：平成 18 年 3 月 4.05 微生物 限度試験法. カンテン平板表面塗抹法. p 80 .

6) 渡辺玲奈, 下田智子, 矢野理香, 良村貞子 : 病床規模 の異なる病院における ATP(アデノシン三リン酸)值を 用いた環境表面清浄度調査. 看科研会誌 $2015 ; 16(1)$ ： $13-21$.

7) Boyce JM: Environmental contamination makes an important contribution to hospital infection. J Hosp Infect 2007; 65: 50-4.

8) Duckro AN, BlomDW, Lyle EA, Weinstein RA, Hayden MK: Transfer of vancomycin-resistant enterococci via health care worker hands. Arch Intern Med 2005; 165: 302-9.

9) Hayden MK, Bonten MJ, Blom DW, Lyle EA, van de Vijver DA, Weinstein RA: Reduction in acquisition of vancomycin-resistant enterococcus after enforcement of routine environmental cleaning measures. Clin Infect Dis 2006; 42: 1552-60.

10) Weber DJ, Rutala WA, Miller MB, Huslage K, Sickbert-Bennett E: Role of hospital surfaces in the transmission of emerging healthcare-associated pathogens: Norovirus, Clostridium difficile, and Acinetobacter species. Am J Infect Control 2010; 38 (5 Suppl 1): S2533.

11) Al-Hamad A, Maxwell S: How clean is clean? Proposed methods for hospital cleaning assesment. J Hosp Infect 2008; 70: 328-34.

12) Siegel JD, Rhinehart E, Jackson M, Chiarello L , HICPAC: 2007 Guideline for Isolation Precautions: Preventing Transmission of Infectious Agents in Healthcare Setting: http://www.cdc.gov/ncidod/dhqp/pdf/isolation2007. pdf. accessed October 26, 2015.

13) Rutala WA, Gergen MF, Weber DJ: Efficacy of Different Cleaning and Disinfection Method against Clostridium difficile Spores:Importance of Physical Removal versus Sporicidal Inactivation. Infect Control Hosp Epidemil 2012; 33: 1255-8.

〔連絡先 : ₹805-0061 北九州市八幡東区西本町 4-18-1 北九州市立八幡病院感染制御室 伊藤重彦 E-mail: ito@yahatahp.jp] 


\title{
Relationship of Frequency of Wiping with Disinfectant and Decrease in Bacteria on Environmental Surfaces in General Wards
}

\author{
Shigehiko Ito ${ }^{1,7)}$, Yuko NakagawA ${ }^{1,7)}$, Hiroko Minami2 ${ }^{2)}$, Osamu Hashimoto ${ }^{3)}$, Yasuko HoriE ${ }^{4)}$, \\ Miki Hiwatashi ${ }^{5)}$, Yukiko Moronaga ${ }^{6)}$, Kazuyo Motoishi ${ }^{7)}$, Hatsumi Taniguchi ${ }^{7)}$ and Tetsuro Matsumoto ${ }^{7)}$ \\ 1)Division of Infection Control and Prevention, Kitakyushu City Yahata Hospital, \\ ${ }^{2)}$ Department of Infection Control and Prevention, Tobata Kyoritsu Hospital, \\ 3) Department of Pharmacy, Tobata Kenwa Hospital, \\ 4) Division of Infection Control and Prevention, Japan Community Health care Organization Kyushu Hospital, \\ 5) Division of Infection Control and Prevention,Shinyukuhashi Hospital, \\ 6) Division of Infection Control and Prevention,Kenwakai Otemachi Hospital, \\ 7) NPO corporation KRICT
}

\begin{abstract}
This study investigated the relationship between frequency of wiping with disinfectant and decrease in bacteria on environmental surfaces in general wards. In the surgical ward of 1 facility, the numbers of bacteria for on multiple environmental surfaces were investigated. Large numbers of living bacteria were detected on the surfaces of a toilet seat, a washing operation panel, and around the faucet in a washhand stand, located in the general ward restroom for patients. Six medical institutions participated in a study of the number of times per day for wiping with disinfectant and the decrease in bacteria in these three places. Two restrooms of each facility were divided into the A group (wiping only once a day in the morning) and the B group (wiping twice a day, morning and evening). Environmental surface wiping continued for 5 days. Specimens were gathered from the three places before wiping on the morning of the first day, second day, and fifth day, and total number of the bacteria, number of living bacteria, adenosine triphosphate (following ATP level) were measured. Wiping methods were unified in 6 facilities, with the wipe immersed in a peroxypotassium hydrogen sulfate (oxidizer) combination agent. The numbers of living bacteria on the environmental surface of a washing operation panel, and around the faucet in a washhand stand decreased in the B group compared with the A group $(\mathrm{p}<0.05)$. The ATP level decreased on the environmental surface of a washing operation panel, and around the faucet in a washhand stand in the B group compared to the A group $(\mathrm{p}<0.05)$. The number of living bacteria around the faucet in a washhand stand did not significantly decrease just after wiping with disinfectant. On multiple investigation points of the general ward restroom, the number of living bacteria on the environmental surface were significantly decreased by increasing the frequency of wiping with disinfectant from once to twice a day.
\end{abstract}

Key words : environmental maintenance, hospital infection, environmental disinfection, disinfectant, wiping 